Available online at GSC Online Press Directory

GSC Biological and Pharmaceutical Sciences

e-ISSN: 2581-3250, CODEN (USA): GBPSC2

Journal homepage: https://www.gsconlinepress.com/journals/gscbps

(RESEARCH ARTICLE)

\title{
Effect of organophosphate pesticide (chlorpyrifos, fipronil, and malathion) on certain organs of Rattus rattus
}

\author{
Yaseen Muhammad, Ehsan Nazia *, Qamar Safi Ur Rehman, Ali Abid, Khan Waqar Ali and Khan Azizullah \\ Department of Zoology, Wildlife and Fisheries, Faculty of Sciences, University of Agriculture Faisalabad 38000, Punjab, \\ Pakistan.
}

Publication history: Received on 26 January 2019; revised on 27 February 2019; accepted on 05 March 2019

Article DOI: https://doi.org/10.30574/gscbps.2019.6.3.0016

\begin{abstract}
The study was conducted to evaluate efficacy of pesticide that effect on histopathology of Rattus rattus under laboratory conditions of $30 \pm 20{ }^{\circ} \mathrm{C}$ and $60 \pm 50 \%$ room humidity in the Biocontrol laboratory at the Department of Zoology, Wildlife and Fisheries, University of Agriculture, Faisalabad. Baits were prepared by pesticides chlorpyrifos, fipronil and malathion as well as adding flour, sugar, cheese, and oil. Baits were given to rats as $4000 \mathrm{mg} / \mathrm{kg}$ of body weight. Animals were kept into four groups, one as control while others as treated with Pesticides chlorpyrifos, fipronil, and malathion. Observations concerning the morphological changes were recorded in the laboratory on regular basis. Visible physiological changes observed. Highly significant (at $\mathrm{p} \leq 0.01$ ) variations found in the results of physical parameters like feed consumption and water intake. Histopathological records showed momentous changes in tissues of the kidney and liver. Necrosis of tissues was noteworthy in all organs. ANOVA was applied on the histopathological level that showed significant variations due to the application of the pesticide.
\end{abstract}

Keywords: Field rat; Pest management; Histology; Pesticide; Organophosphate; Efficacy

\section{Introduction}

Rodents are caused large damaged to foods as well as crop. Their presence at a particular place is related to food availability [1]. Field rats are confined in Indian as well as Pakistan [2]. The presence of 40 rats in a grain market result in $740 \mathrm{~kg}$ loss annually [3]. Rodents prefer to consume grains because they readily provide them energy [4]. Pesticides are intended to destroy or causes the destruction of organisms other than insects, including humans due to their hazardous and long-term effects. Temporary effects of pesticides include nausea to chronic impacts like cancer and headaches, endocrine disarray, reproductive damage, and nervous system are associated to an extensive assortment of person health danger, deposit from pesticides [5].

Severe poisoning and familiar symptoms include mycosis, diarrhea, increased urination, lacrimation, diaphoresis, and salivation may occur by pesticides [6]. According to WHO about 3 million cases of pesticides poisoning occur every year, resulting in more than 250,000 deaths [7]. The pesticides of synthetic nature are quick in their action but also hazardous for the surrounding population [8]. The probable increase in environmental pollution is increasing the risk of damage in peoples [9].

Malathion and chlorpyrifos are the extensive utilization of insecticides in the harvesting of crops and household applications Acetylcholine also inhibited by organophosphate compounds like chlorpyrifos irreversibly. CPF is nonsystematic insecticide which causes poisoning when used in agriculture, accidental exposure and rarely homicide [10]. Toxicity of pesticide causes serious effects on different organs including the liver, kidney, brain, blood cells [11].

\footnotetext{
${ }^{*}$ Corresponding author

E-mail address: nazia.ehsan@uaf.edu.pk
} 
The metabolic adjustments of lipids; thus, carbohydrates proteins and influencing the functional status of all major body organs including heart, liver, kidney, bones, muscles and nervous system in animals inclined by adrenal hormones directly [12]. The kidney and liver are the major organs that detoxify the poisons and pesticides, ultimately reduces the effect of toxicity on the organs of organisms. The main function in the biotransformation of pesticides is played by them. The concerned balance among the level of oxidative stress and the antioxidant potential induce compassion of these tissues stress to pesticides [13].

This study was conducted to check the damage of three organophosphate pesticides on the physiology of Rattus rattus. These pesticides are chlorpyrifos, fipronil, and malathion which are commonly used to control the pest. Their damage was observed on major organs such as the brain, kidney, and tissues of the body.

\section{Material and methods}

The materials which were used the collection of rats, electric grinder, cages, sieve, gloves, Chloroform, weight balance, cotton, stirrer, and beakers.

\subsection{Study area}

In the region of central Punjab, Pakistan which is located between latitude $30^{\circ} 31.5^{\circ}$ north longitude $73^{\circ} 74^{\circ}$ toward the east, 184.4 meters above sea level with a highest standard temperature of $35^{\circ} \mathrm{C}$ throughout summer and least standard temperature of $-5^{\circ} \mathrm{C}$ District Faisalabad is located. Whereas, approximately $2000 \mathrm{~mm}(79 \mathrm{In})$ rainfall which is adequate to keep the soil dreadfully productive. Rabi and Kharif crops are sophisticated here. This study has been conducted in February. The required sugarcane, wheat, and rice field were located to make the beginning survey. From different localities of Dhobi Wala and Gut Wala, the data has collected.

\subsection{Collection of rats}

From wheat fields of Faisalabad Field rats have caught. For one week earlier than the initiation of experiment rats have familiarized individually in cages of suitable size in the laboratory. They have provided with proper food and water. Metallic trays will be kept under each cage for the collection of waste food and removal of urine and feces.

\subsection{Formation of bait}

A bolus of weight $45 \mathrm{~g}$ has prepared consist of poultry feed. To prepare the bolus $3.5 \mathrm{mg} / \mathrm{kg}$ concentration of chlorpyriphos and has added. For proper results variation in the extract, concentration has reserved. The bait becomes moisturized due to ethanolic content, so the bait has dehydrated under the shade to decrease the moisture content of feed after the formation of bait of suitable size and weight with the proper concentration of the ethanolic extract.

\subsection{Application of bait}

Treated rats have been given by the feed including the extract. The control rats have only offered with feed. Food was in form of a bolus which has provided. Two weeks of the trial was conducted. To define the results 5 replicate has formed. For daily basis data for water and food consumed has taken.

\subsection{Experimental design}

The trial plan has formed to study the variation in the data for water and food intake and variation in the morphology while the fur color and fur texture and behavior response to a food stimulus. The difference in food ingestion of $1^{\text {st }}$ week after giving the dose of organophosphate was pragmatic on daily basis in field rat that demonstrates differences in food utilization and water drinking. The fipronil applied to rats for 1 week and the body weight increase within the first week and the slight change in liver and kidney tissues weight. But for the second week, the fipronil was exposed to rats. The most subtle and foremost target body part of pesticide toxicity and destruction are liver and kidney.

\subsection{Statistical analysis}

Analyzed by using the Minitab18 has the results of the hematobiochemical analysis. Followed by Dennett's test comparisons have prepared between the experimental groups by using one-way analysis of variance (ANOVA). As statistically important values of less than 0.05 were regarded. 


\section{Results and discussion}

This study was an effort to check the effect of different pesticides on the histology of field rats. This study was designed to investigate alternations of tissues in field rats by pesticides which were used for controlling the pest and increase the harvest in agriculture. Some chemicals affect the non-target species and pollute the environment. Two experiments were designed with six rats for 14 days.

The fipronil cause damage in Fipronil delicacy group as evaluate to the controlled group. The level of creatinine and uric acid increased in Fipronil treated groups. The overproduction of creatinine and uric acid cause inability of excretion. The enzymes also increased in fipronil treated group and it increases liver and kidney weight and causes the change in permeability of liver and kidney. It induced oxidative stress in rats which reduced the body weight due to toxicity. It was also responsible for the detoxification process.

In the second week, the body weight is decreased due to toxicity and the liver and kidney weight slightly increased.it can be accomplished that FPN provokes peroxidation of lipid, oxidative pressure in kidney and liver damage in rats. This pathophysiological modification in kidney and liver tissues could be due to the poisonous effect of FPN that related to the generation of free radicals.

Pesticides affect the histology of field rats. Pesticide such as fipronil was applied by water intake. Histopathological changes in the kidney and liver of male gender of rats caused by Fipronil. From our outcomes, it can be concluded that in rats, peroxidation of lipid, oxidative stress, kidney and liver injury induced by Fipronil. As a result, in the liver tissues severely congested central vein and blood sinusoids were detected in the imidacloprid-treated group, throughout the hepatic tissue pyknotic nuclei were found, and leukocytes infiltration was observed. We observed Variation of food consumption in controlled and treated rats and variation of water intake in controlled and treated groups. Different readings were taken and graphed it. So, we concluded that pesticides effects on histology of field rats. The results were analyzed statistically by ANOVA.

Table 1 Effect of fipronil on oxidative pressure biomarkers in liver tissues of rats

\begin{tabular}{|l|l|l|l|l|l|l|}
\hline Treatment & $\begin{array}{l}\text { SOD }(\mathbf{U} / \mathbf{m g} \\
\text { Protein) }\end{array}$ & $\begin{array}{l}\text { CAT }(\boldsymbol{\mu m o l} / \mathbf{m g} \\
\text { Protein) }\end{array}$ & $\begin{array}{l}\text { GST }(\boldsymbol{\mu m o l} / \mathbf{m g} \\
\text { Protein) }\end{array}$ & $\begin{array}{l}\text { GPx (U/mg } \\
\text { Protein) }\end{array}$ & $\begin{array}{l}\text { GSH ( } \boldsymbol{\mu m o l} / \mathbf{m g} \\
\text { Protein) }\end{array}$ & $\begin{array}{l}\text { LPO (nmol/ } \\
\text { g Protein) }\end{array}$ \\
\hline 1 & $6.76 \pm 0.12$ & $13.93 \pm 0.26$ & $0.53 \pm 0.018$ & $7.87 \pm 0.35$ & $0.087 \pm 0.003$ & $74.35 \pm 2.45$ \\
\hline$Ц$ & $6.92 \pm 0.15$ & $13.65 \pm 0.43$ & $0.52 \pm 0.008$ & $5.97 \pm 0.41$ & $0.086 \pm 0.003$ & $78.28 \pm 3.24$ \\
\hline Ш & $6.93 \pm 0.24$ & $13.01 \pm 0.29$ & $0.51 \pm 0.005$ & $5.32 \pm 0.40$ & $0.081 \pm 0.0014$ & $87.72 \pm 2.57$ \\
\hline Iv & $5.54 \pm 0.08$ & $8.01 \pm 0.27$ & $0.43 \pm 0.013$ & $3.62 \pm 0.28$ & $0.058 \pm 0.003$ & $111.86 \pm 4.22$ \\
\hline
\end{tabular}

Six animals each value has a means \pm SE. Means have the identical letters are not considerably different from everyone, $\mathrm{p}<0.05$ control and treated group.

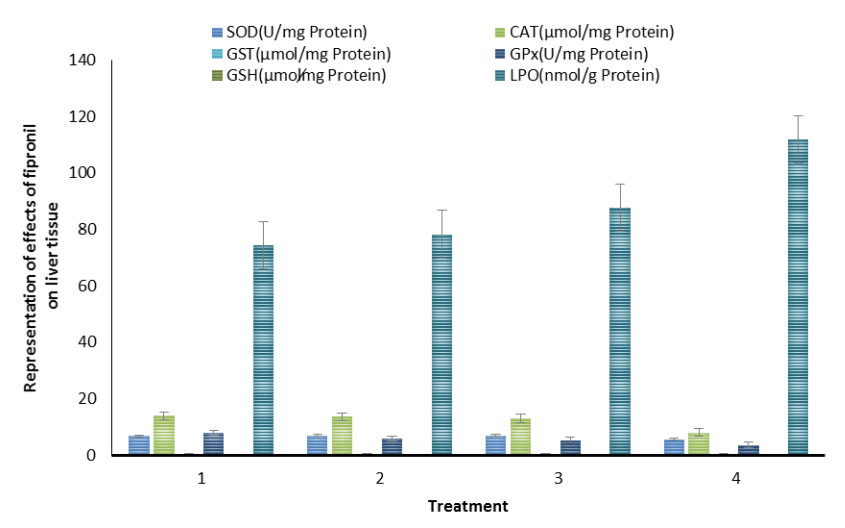

Figure 1 Chemical representation of effects of fipronil on liver tissue 
Table 2 Histological modification with different treatments

\begin{tabular}{|c|c|c|c|c|}
\hline \multirow{2}{*}{$\begin{array}{l}\text { Histopathological } \\
\text { alternation }\end{array}$} & \multicolumn{4}{|c|}{ Level of Signification during treatments } \\
\hline & Treatment I & Treatment II & Treatment III & Treatment IV \\
\hline \multicolumn{5}{|l|}{ Liver } \\
\hline $\begin{array}{l}\text { Hepatocytes } \\
\text { degeneration }\end{array}$ & $\begin{array}{l}\text { Non-significant/ } \\
\text { Nil }\end{array}$ & $\begin{array}{l}\text { Less Significant/ } \\
\text { Mild }\end{array}$ & $\begin{array}{l}\text { More-Significant/ } \\
\text { Severe }\end{array}$ & $\begin{array}{l}\text { More-Significant/ } \\
\text { Severe }\end{array}$ \\
\hline $\begin{array}{l}\text { Central-vein } \\
\text { congestion }\end{array}$ & $\begin{array}{l}\text { Non-significant/ } \\
\text { Nil }\end{array}$ & $\begin{array}{l}\text { Less significant/ } \\
\text { Mild }\end{array}$ & $\begin{array}{l}\text { Non-significant/ } \\
\text { Nil }\end{array}$ & $\begin{array}{l}\text { Non-significant/ } \\
\text { Nil }\end{array}$ \\
\hline $\begin{array}{l}\text { Portal Infiltration } \\
\text { among } \\
\text { Inflammatory cells }\end{array}$ & $\begin{array}{l}\text { Non-significant/ } \\
\text { Nil }\end{array}$ & $\begin{array}{l}\text { Less significant/ } \\
\text { Mild }\end{array}$ & $\begin{array}{l}\text { Significant/ } \\
\text { Moderate }\end{array}$ & $\begin{array}{l}\text { More-Significant/ } \\
\text { Severe }\end{array}$ \\
\hline $\begin{array}{l}\text { Oval cells } \\
\text { proliferation }\end{array}$ & $\begin{array}{l}\text { Non-significant/ } \\
\text { Nil }\end{array}$ & $\begin{array}{l}\text { Non-significant/ } \\
\text { Nil }\end{array}$ & $\begin{array}{l}\text { Non-Significant/ } \\
\text { Nil }\end{array}$ & $\begin{array}{l}\text { Significant/ } \\
\text { Moderate }\end{array}$ \\
\hline $\begin{array}{l}\text { Focal hepatic } \\
\text { hemorrhage }\end{array}$ & $\begin{array}{l}\text { Non-significant/ } \\
\text { Nil }\end{array}$ & $\begin{array}{l}\text { Non-significant/ } \\
\text { Nil }\end{array}$ & $\begin{array}{l}\text { Non-significant/ } \\
\text { Nil }\end{array}$ & $\begin{array}{l}\text { Significant/ } \\
\text { Moderate }\end{array}$ \\
\hline $\begin{array}{l}\text { Cystic dilation of bile } \\
\text { duct }\end{array}$ & $\begin{array}{l}\text { Non-significant/ } \\
\text { Nil }\end{array}$ & $\begin{array}{l}\text { Non-significant/ } \\
\text { Nil }\end{array}$ & $\begin{array}{l}\text { Non-significant/ } \\
\text { Nil }\end{array}$ & $\begin{array}{l}\text { Non-significant/ } \\
\text { Nil }\end{array}$ \\
\hline \multicolumn{5}{|l|}{ Kidney } \\
\hline $\begin{array}{l}\text { Focal necrosis of renal } \\
\text { tubules }\end{array}$ & $\begin{array}{l}\text { Non-significant/ } \\
\text { Nil }\end{array}$ & $\begin{array}{l}\text { Non-significant/ } \\
\text { Nil }\end{array}$ & $\begin{array}{l}\text { Non-significant/ } \\
\text { Nil }\end{array}$ & $\begin{array}{l}\text { More-Significant/ } \\
\text { Severe }\end{array}$ \\
\hline $\begin{array}{l}\text { Epithelial lining \& } \\
\text { Renal-tubules } \\
\text { Vacuolation }\end{array}$ & $\begin{array}{l}\text { Non-significant/ } \\
\text { Nil }\end{array}$ & $\begin{array}{l}\text { less-Significant/ } \\
\text { Nil }\end{array}$ & $\begin{array}{l}\text { Significant/ } \\
\text { Moderate }\end{array}$ & $\begin{array}{l}\text { More-Significant/ } \\
\text { Severe }\end{array}$ \\
\hline $\begin{array}{l}\text { Renal-focal } \\
\text { hemorrhage }\end{array}$ & $\begin{array}{l}\text { Non-significant/ } \\
\text { Nil }\end{array}$ & $\begin{array}{l}\text { Non-significant/ } \\
\text { Nil }\end{array}$ & $\begin{array}{l}\text { Significant/ } \\
\text { Moderate }\end{array}$ & $\begin{array}{l}\text { More-Significant/ } \\
\text { Severe }\end{array}$ \\
\hline
\end{tabular}

The sternness of the response in kidney and liver tissues of control and experimental groups according to the histopathological modification. Control group II, III and IV, received FPN at the concentration of 1.0, 1.1 and 10.o mg/L.

Table 3 The chlorpyrifos and malathion affects the tissues of the liver, kidney, and brain

\begin{tabular}{lll}
\hline Tissues & Chlorpyrifos & Malathion \\
\hline Liver & $3.87 \pm 0.09$ & $3.57 \pm 0.19$ \\
Kidney & $3.10 \pm 0.73$ & $3.82 \pm 0.17$ \\
Brain & $12.79 \pm 0.84$ & $11.68 \pm 0.46$ \\
\hline
\end{tabular}

\section{Conclusion}

This experiment shows us that all three pesticides are equally effective against rat control. However, it only is used in the field by the recommendation of the pest manager. Because excessive use can harm humans and animal who eat those crops. 


\section{Compliance with ethical standards}

\section{Acknowledgments}

We thank Miss. Nazia Ehsan for providing us the opportunity to carry out this work. Moreover, all the authors contributed equally to the experiment.

\section{Disclosure of conflict of interest}

There is no conflict of interest among authors.

\section{Statement of ethical approval}

This work was carried out by the approval of Dr. Hammad Ahmad Khan Chairman Department of Zoology, Wildlife, and Fisheries, University of Agriculture, Faisalabad 38000, Punjab, Pakistan.

\section{References}

[1] Sarwar M. (2015). Species complex, damage pattern and efficiency of rodenticides in controlling rodents attacking rice (Oryza sativa L.) fields. International Journal of Animal Biology, 1(5), 202-208.

[2] Molur S, Srinivasulu C, Walker S, Nameer PO and Ravikumar L. (2005). Status of south Asian non-volant small mammals: conservation assessment and management plan (CAMP) workshop report. Zoo Outreach Organization/CBSG-South Asia, Coimbatore, India, 618.

[3] Ahmad E, Hussain I and Brooks JE. (1995). Losses of stored foods due to rats at grain markets in Pakistan. International Biodeterioration \& Biodegradation, 36(1-2), 125-133.

[4] Shafi MM, Ahmed S, Ahmed SM and Pervez A. (1991). Taste additives improve poison bait acceptance in Indian gerbil, Tatera indica. Journal of Plant Protection in the Tropics, 8, 77-83.

[5] Keifer MC and Firestone J. (2007). Neurotoxicity of pesticides. Journal of Agromedicine, 12(1), 17-25.

[6] Hazarika R. (2013). Neurotoxic impact of organophosphate pesticide phosphomedon on the albino rat. Journal of Environmental Biology, 35(2), 427-430.

[7] Yang C and Deng J. (2007). Intermediate syndrome following organophosphate insecticide poisoning. Journal of the Chinese Medical Association, 70(11), 467-472.

[8] Zartashia A, Hanif MA, Khan RW and Khan MM. (2014). Role of essential oils in plant diseases protection. International Journal of Chemical and Biochemical Sciences, 6: 11-17.

[9] Liu Y, Xu Z, Wu X, Gui W and Zhu G. (2010). Adsorption and desorption behavior of herbicide diuron on various Chinese cultivated soils. Journal of Hazardous Materials. 178(1-3), 462-468.

[10] Yurumez Y, Ikekeizceli I, Sozuer CM, Soyuer I and Yavuz Y. (2007). Effect of interleukin-10 on Tissue Damage caused by organophosphate poisoning. Basic and Clinical Pharmacology and Toxicology; 100, 323-327.

[11] Bebe FN and Panemanogalore M. (2003). Exposure of low doses of endosulfan and chlorpyrifos modifies endogenous antioxidants in tissues of rats. Journal of Environmental Science and Health, 38(3), 349-363.

[12] Harvey PW. (2016). Adrenocortical endocrine disruption. The Journal of Steroid Biochemistry and Molecular Biology, 155, 199-206.

[13] Mansour SA and Mossa AT. (2010). Oxidative damage, biochemical and histopathological alterations in rats exposed to chlorpyrifos and the antioxidant role of zinc. Pesticide Biochemistry and Physiology, 96(1), 14-23.

\section{How to cite this article}

Yaseen M, Ehsan N, Qamar SUR, Ali A, Khan WA and Khan A. (2019). Effect of organophosphate pesticide (chlorpyrifos, fipronil, and malathion) on certain organs of Rattus rattus. GSC Biological and Pharmaceutical Sciences, 6(3), 11-15. 